\title{
Parathyroid Hormone as a Marker for the Red Cell Fragility in Different Stages of Chronic Kidney Disease
}

\author{
Said Sayed Ahmed Khamis', Yassin Salah Yassin Mohamed1, Heba El Sayed Kasem1, \\ Thoria Ahmed Omar², Hend Samir Mohammed Shaaban ${ }^{3}$
}

${ }^{1}$ Internal Medicine Department, Faculty of Medicine, Menoufia University, Shebin El Kom, Egypt

${ }^{2}$ Clinical Pathology Department, Faculty of Medicine, Menoufia University, Shebin El Kom, Egypt

${ }^{3}$ Nephrology Department, Police Hospital, New Cairo, Cairo, Egypt

Email: dedy2010_ajh@hotmail.com

How to cite this paper: Khamis, S.S.A., Mohamed, Y.S.Y., El Sayed Kasem, H., Omar, T.A. and Shaaban, H.S.M. (2021) Parathyroid Hormone as a Marker for the Red Cell Fragility in Different Stages of Chronic Kidney Disease. Open Journal of Nephrology, 11, 123-132.

https://doi.org/10.4236/ojneph.2021.111010

Received: February 1, 2021

Accepted: March 28, 2021

Published: March 31, 2021

Copyright $\odot 2021$ by author(s) and Scientific Research Publishing Inc. This work is licensed under the Creative Commons Attribution International License (CC BY 4.0).

http://creativecommons.org/licenses/by/4.0/

\begin{abstract}
Objective: The aim of the work is to study the relationship between Red blood cell osmotic fragility and level of parathyroid hormone in patients with different stages of Chronic Kidney Disease including End Stage Renal Disease. Background: Anaemia is one of the common complications associated with Chronic Kidney Disease (CKD) responsible for the increase in the morbidity and mortality in such patients. Several factors have been attributed to causing renal anaemia, amongst which hyperparathyroidism is one of the less recognised reasons. The level of PTH in early stages of chronic kidney disease has not been much studied. The excess amount of Parathyroid Hormone (PTH) secondary to CKD has been suggested to be a causative factor for anaemia. Method: A number of chronic kidney disease patients were studied for the relationship between Red cell osmotic fragility and level of parathyroid hormone. Results: This study was conducted on a number of 111 patients with chronic kidney disease classified into three groups. The study revealed a significant fall in $\mathrm{Hb} \%$, along with a rise in Median Osmotic Fragility (MOF) and PTH in the CKD patients. iPTH and MOF were significantly lower in group 3 as compared with cases in group 1. Also, iPTH and MOF were significantly lower in cases in group 2 as compared with cases in group 1. Conclusions: Based on our findings, secondary hyperparathyroidism has considerable effects on erythrocyte survival, contributing to increased fragility and anemia.
\end{abstract}

\section{Keywords}

Chronic Kidney Disease, Renal Anemia, Red Cell Osmotic Fragility, Secondary Hyperparathyroidism 


\section{Introduction}

Anaemia is a common complication in CKD patients, who have a mortality rate 20 - 100 times higher than the normal population. Several studies have revealed the association of hyperparathyroidism with CKD. Parathyroid hormone (PTH) is a major uremic toxin which may be responsible for long term consequences in CKD such as renal osteodystrophy, vascular calcification, altered cardiovascular function, immune dysfunction and anaemia [1]. One of the lesser known functions of the kidneys is the production of erythropoietin, a signaling molecule that stimulates red blood cell production, in response to decreased oxygen levels in the blood. Any disruption of this process, e.g., secondary to a functional abnormality due to $\mathrm{CKD}$, has the potential to produce anemia, a condition in which the number of circulating red blood cells, and therefore the level of hemoglobin, is lower than normal [2].

Secondary hyperparathyroidism is characterized by elevated serum parathyroid hormone (PTH) levels. Excess PTH may impair erythropoiesis by exerting a direct toxic effect on erythroid progenitor cells and an indirect effect through bone marrow fibrosis induction. In addition, low hemoglobin concentration in uremic patients may have resulted from an increase in erythrocyte osmotic fragility due to high PTH concentration [3]. In advanced CKD, high PTH levels may cause "resistance" to erythropoietin by increasing bone marrow fibrosis, increase the osmotic fragility of red blood cells, leading to a shortened lifespan, and inhibit the proliferation of erythroid precursors [4]. According to the various studies, an increase in serum level of iPTH leads to a decrease in serum level of hemoglobin among hemodialysis patients [5].

\section{Patients and Methods}

This work is aimed to study the relationship between red blood cells osmotic fragility and level of parathyroid hormone in patients with different stages of chronic kidney disease including end stage renal disease.

This cross-sectional study was conducted on 111 patients with CKD during the period of one year (from March 2019 till February 2020), patients were divided into three groups according to GFR into Group I: ESRD (GFR from $<15$ $\mathrm{min} / \mathrm{ml} / 1.73 \mathrm{~m}^{2}$ ) patient on regular hemodialysis more than 3 months. Group 2: CKD stage 4 (GFR from $15-29 \mathrm{~min} / \mathrm{ml} / 1.73 \mathrm{~m}^{2}$ ). Group 3: CKD stage 3 (GFR from $30-59 \mathrm{~min} / \mathrm{ml} / 1.73 \mathrm{~m}^{2}$ ). We included patients older than 18 years with different stages of chronic kidney disease and we excluded patients with cardiovascular diseases, inflammatory diseases, patients with hemolysis and active bleeding. The study followed the ethical standards of Faculty of Medicine, Menofia University and was approved by ethical committee of the faculty. The following data were analyzed for all patients: Age, Gender and routine laboratory investigations: $\mathrm{CBC}, \mathrm{Ca}$, Phos, $\mathrm{Na}, \mathrm{K}$, Iron profile, kidney functions, liver functions, iPTH (Serum intact Parathyroid Hormone (iPTH) was measured using chemiluminiscence immuno assay by Beckmann Coulte and by using Serolia tm 
Human Intact PTH ELISA Kit) and MOF (Red cell osmotic fragility was evaluated by incubating $50 \mu \mathrm{l}$ of the RBC of the patients' sample with gradually increasing concentrations of $\mathrm{NaCl}$ ranging from $0.1 \%$ to $0.9 \%$. After one hour, the incubated solutions were centrifuged and the absorbance of the supernatant was taken at $540 \mathrm{~nm}$. A curve was plotted based on the concentration of $\mathrm{NaCl}$ and absorbance reading. The concentration of $\mathrm{NaCl}$ causing $50 \%$ hemolysis is taken as the Median Osmotic Fragility (MOF).

\section{Results}

The collected data were coded, processed and analyzed using the SPSS (Statistical Package for Social Sciences) version 22 for Windows ${ }^{\circledR}$ (IBM SPSS Inc, Chicago, IL, USA). Data were tested for normal distribution using the Shapiro Walk test. Qualitative data were represented as frequencies and relative percentages. Chi square test $\left(\chi^{2}\right)$ was used to calculate difference between qualitative variables as indicated. Quantitative data were expressed as mean \pm SD (Standard deviation). One-way analysis of the variance one-way ANOVA was used to compare between three independent groups of normally distributed variables (parametric data) while Kruskal wallis test was used for non-normally distributed Data (non-parametric data). Significance test results are quoted as two-tailed probabilities. For all the above-mentioned tests, the level of significance was tested, expressed as the probability of ( $p$-value) and the results were explained as following:

Non-significant if the $\mathrm{p}$ value is $>0.05$, Significant if the $\mathrm{p}$ value is $\leq 0.05$, highly significant if the $\mathrm{p}$ value $<0.001$. There is a statistically significant negative correlation between MOF with HGB, RBCs, MCV, platelets count, calcium and GFR (Figure 1). There is a statistically significant difference between the cases within the three study groups in Calcium, Phosphorous, $\mathrm{Ca}^{\star} \mathrm{PH}, \mathrm{Na}, \mathrm{K}, \mathrm{TIBC}$, Total saturation, Serum albumin, iPTH and MOF. iPTH and MOF were significantly lower in cases with stage 3 as compared with cases in stage 5. Also, iPTH and MOF were significantly lower in cases in stage 4 as compared with cases in stage 5. (Figure 2) There is a statistically significant positive correlation between MOF with Creatinine, Urea, Phosphorous, $\mathrm{Ca}^{*}$ phosphorous product, K, KTV and PTH.

\section{Discussion}

There are various causes of renal anemia such as decreased production of erythropoietin (EPO), resistance to EPO, shortened survival of red blood cells (RBCs), and bone marrow fibrosis. Secondary hyperparathyroidism (SHPT) is a less recognized, but potentially significant cause of renal anemia in CKD patients.

Parathyroid hormone (PTH) has been regarded as a uremic toxin that potentially inhibits EPO synthesis, shortens the survival of RBCs, and causes myelofibrosis and thereby decreases hematopoiesis [6]. This current study was conducted to study the relationship between red blood cells osmotic fragility and 


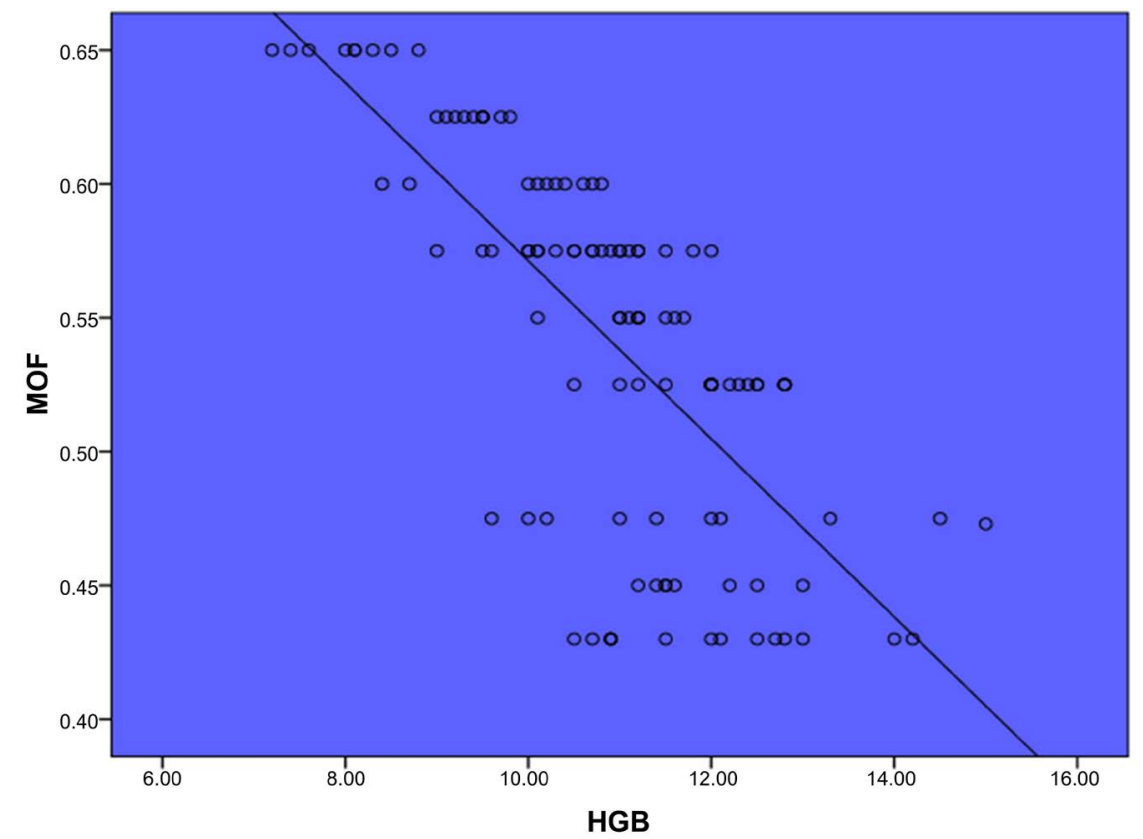

Figure 1. Linear regression analysis of $\mathrm{PTH}$ with $\mathrm{Hb} \%$. X-Axis- $\mathrm{Hb}$ in $\mathrm{gm} / \mathrm{ml}$, Y axis MOF in \%; $\mathrm{X}$ axis: $\mathrm{Hb}$ level in $\mathrm{mg} / \mathrm{dl} ; \mathrm{Y}$ axis:MOF in \%.

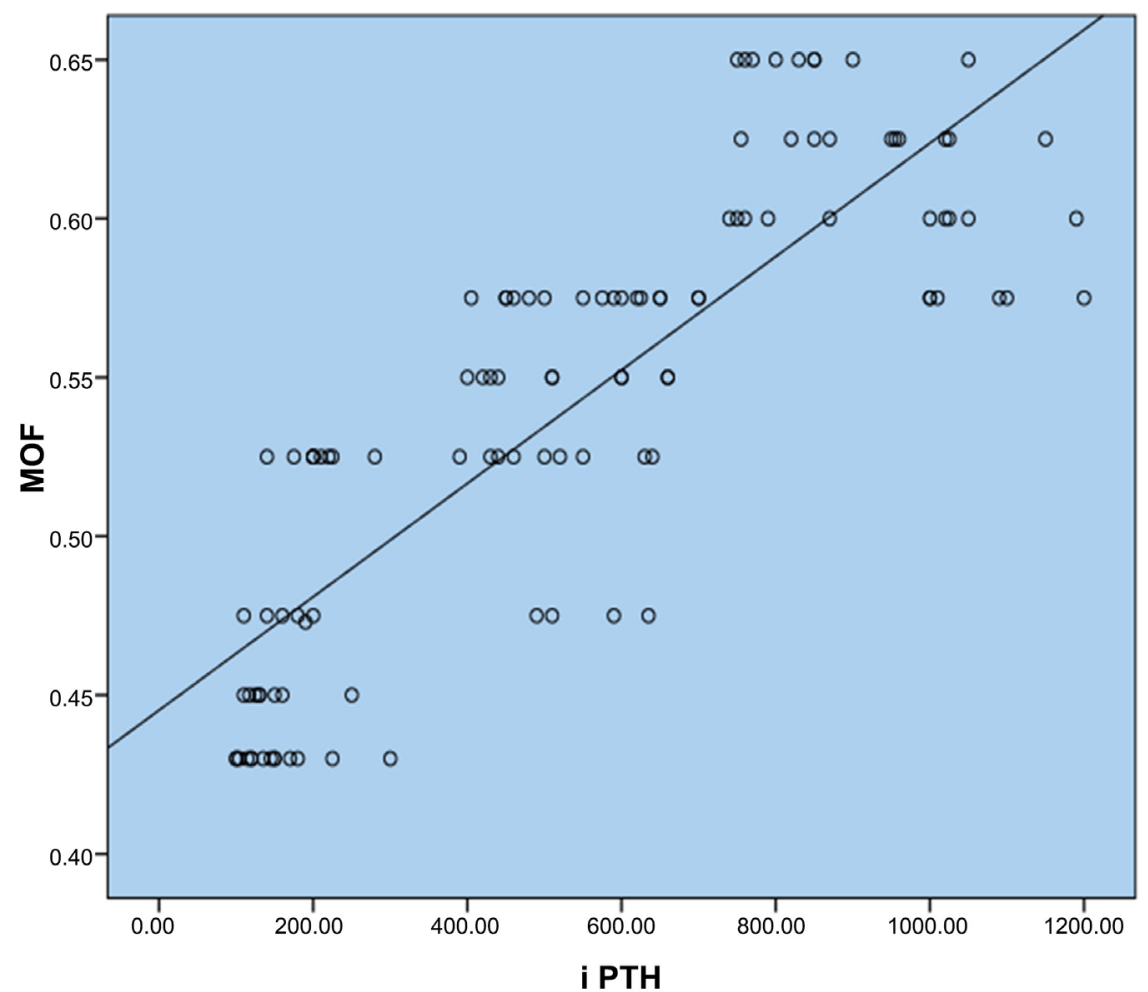

Figure 2. Linear regression analysis of MOF with PTH. X-Axis PTH in pg/ml, Y axis Median Osmotic Fragility in \%; $\mathrm{X}$ axis $\mathrm{iPTH}$ in pg/ml; $\mathrm{Y}$ axis MOF in \%; statistically significant $(\mathrm{r}=0.836, \mathrm{p}<0.001)$.

level of parathyroid hormone in patients with different stages of chronic kidney disease including end Stage Renal disease. To the best of our knowledge, there is 
gust one study available in the literature that studies the effect of CKD on the osmotic fragility of RBCs. This study included 111 patients with chronic kidney disease, stage 3 - 5. There were 37 patients in each stage. In this study, the mean age of the cases didn't reveal a statistically significant difference in the study groups $(\mathrm{p}=0.586)$. There was no statistically significant difference in the sex distribution between the cases within the three study groups (Males represent $56.8 \%, 48.7 \%$ and $54.1 \%$ in the cases in Stage III, IV and V CKD respectively) (Table 1). Similar results were reported by Janmaat et al. who showed that participants with CKD stage 5 were younger and more often men than the patients with CKD stages 3 to 4 [7]. A gender-different prevalence of CKD was discovered in most related studies. Higher prevalence of CKD in women compared with men as reported in many studies [8]. Also, the serum hemoglobin level was $9.65 \pm 1.28 \mathrm{~g} / \mathrm{dl}$ in cases with stage V CKD, $11.18 \pm 1.16 \mathrm{~g} / \mathrm{dl}$ in cases with stage IV CKD and $11.89 \pm 1.12 \mathrm{~g} / \mathrm{dl}$ in cases with stage III with high statistically significant difference between the three groups. This agreed with Janmaat et al. who showed that the mean serum of hemoglobin level was $134.7 \pm 15.2 \mathrm{~g} / \mathrm{dl}$, $129.2 \pm 15.7 \mathrm{~g} / \mathrm{dl}, 123.8 \pm 15.7 \mathrm{~g} / \mathrm{dl}$ and $119.1 \pm 16.5 \mathrm{~g} / \mathrm{dl}$ in cases with stage $3 \mathrm{a}, 3 \mathrm{~b}, 4$ and $5 \mathrm{CKD}$ respectively, with high statistically significant difference between the four groups (Table 2, Table 3) [7]. Similar results were shown by Finkelstein et al. where the mean Hgb levels were 12.8 in stage 3 patients, 12.0 in stage 4 patients, and 11.4 in stage 5 patients $(\mathrm{P}=0.023)$ [9], Anemia in CKD patients is recognized to be multifactorial. Anemia prevalence in CKD patients increases from $26 \%$ to $75 \%$ when the renal function decreases from $>60 \mathrm{ml} / \mathrm{min}$ to $<15 \mathrm{ml} / \mathrm{min}$ most probably because of EPO deficiency [10], EPO deficiency is sometimes not only attributed to the kidney disease but also to another concomitant chronic disease [11]. Interestingly also, Mercadal et al. have shown that anemia in CKD patients with eGFR $>30 \mathrm{ml} / \mathrm{min}$ should be explained by other factors than EPO deficiency [12]. Treating patients with ESA while they suffer from other causes of anemia will lead to EPO resistance. Therefore, anemia in CKD patients when secondary to iron deficiency does not need ESA treatment unless it persists after iron replenishing [13]. In the current study, the serum level of $\mathrm{iPTH}$ was $916.49 \pm 142.34 \mathrm{ng} / \mathrm{L}$ in cass with stage V CKD, $530.27 \pm 86.25$

Table 1. Demographic data of the cases in the three study groups.

\begin{tabular}{ccccc}
\hline Items & $\begin{array}{c}\text { Group A } \\
{[\text { ESRD] }} \\
(\mathbf{n}=37)\end{array}$ & $\begin{array}{c}\text { Group B } \\
{[\text { CKD stage 4] }} \\
(\mathbf{n}=37)\end{array}$ & $\begin{array}{c}\text { Group C } \\
{[\text { CKD stage 3] }} \\
(\mathbf{n}=37)\end{array}$ & $\begin{array}{c}\text { Test of } \\
\text { significance }\end{array}$ \\
\hline Age (years) & $51.81 \pm 9.25$ & $51.95 \pm 6.94$ & $53.62 \pm 8.74$ & $\begin{array}{c}\mathrm{F}=0.538 \\
\mathrm{P}=0.586\end{array}$ \\
Males & & Sex & & \\
Females & $20(54.1 \%)$ & $18(48.7 \%)$ & $21(56.8 \%)$ & $\chi^{2}=1.543$ \\
\hline
\end{tabular}

Continuous data expressed as mean $\pm \mathrm{SD}$. Categorical data expressed as Number (\%); P: intergroup significance; F: one-way ANOVA; $\chi^{2}$ : Chi square test. 
Table 2. Clinical data of the cases in the three study groups.

\begin{tabular}{ccccc}
\hline Items & $\begin{array}{c}\text { Group A } \\
{[\text { ESRD }} \\
(\mathrm{n}=37)\end{array}$ & $\begin{array}{c}\text { Group B } \\
{[\text { CKD stage 4] }} \\
(\mathrm{n}=37)\end{array}$ & $\begin{array}{c}\text { Group C } \\
{[\text { CKD stage 3] }} \\
(\mathrm{n}=37)\end{array}$ & $\begin{array}{c}\text { Test of } \\
\text { significance }\end{array}$ \\
\hline Pulse (b/min) & $82.95 \pm 4.65$ & $81.95 \pm 3.70$ & $81.35 \pm 3.62$ & $\begin{array}{c}\mathrm{F}=1.488 \\
\mathrm{P}=0.230\end{array}$ \\
HTN & $37(100 \%)$ & $36(97.3 \%)$ & $36(97.3 \%)$ & $\begin{array}{c}\chi^{2}=0.453 \\
\mathrm{P}=0.601\end{array}$ \\
& & & & $\begin{array}{c}\chi^{2}=0.506 \\
\mathrm{P}=0.396\end{array}$ \\
\hline
\end{tabular}

Continuous data expressed as mean \pm SD. Categorical data expressed as Number (\%); F: one way ANOVA; $\chi^{2}$ : chi square test; P: intergroup significance.

Table 3. Analysis of the laboratory data in the three study groups.

\begin{tabular}{|c|c|c|c|c|}
\hline Items & $\begin{array}{l}\text { Group A } \\
\text { [ESRD] } \\
(n=37)\end{array}$ & $\begin{array}{c}\text { Group B } \\
\text { [CKD stage 4] } \\
(n=37)\end{array}$ & $\begin{array}{c}\text { Group C } \\
\text { [CKD stage 3] } \\
(\mathrm{n}=37)\end{array}$ & $\begin{array}{c}\text { Test of } \\
\text { significance }\end{array}$ \\
\hline HGB (gm/dl) & $9.65 \pm 1.28$ & $11.18 \pm 1.16 \mathrm{a}$ & $11.89 \pm 1.12 \mathrm{a}, \mathrm{b}$ & $\begin{array}{l}\mathrm{F}=34.325 \\
\mathrm{P}<0.001^{\star}\end{array}$ \\
\hline $\operatorname{RBCs}\left(10^{6} / \mathrm{mcl}\right)$ & $3.68 \pm 0.42$ & $3.96 \pm 0.31 \mathrm{a}$ & $3.91 \pm 0.25 \mathrm{a}$ & $\begin{array}{c}\mathrm{F}=7.374 \\
\mathrm{P}=0.001^{\star}\end{array}$ \\
\hline $\mathrm{MCV}$ & $84.57 \pm 4$ & $82.89 \pm 3.57$ & $84.43 \pm 3.23$ & $\begin{array}{l}F=2.453 \\
P=0.091\end{array}$ \\
\hline $\mathrm{MCH}$ & $27.64 \pm 1.88$ & $28.15 \pm 1.74$ & $29.06 \pm 1.55 \mathrm{a}$ & $\begin{array}{l}\mathrm{F}=6.417 \\
\mathrm{P}=0.002^{\star}\end{array}$ \\
\hline WBCs $\left(10^{3} / \mathrm{mcl}\right)$ & $6.57 \pm 1.30$ & $6.51 \pm 1.26$ & $6.35 \pm 1.25$ & $\begin{array}{l}\mathrm{F}=0.275 \\
\mathrm{P}=0.774\end{array}$ \\
\hline Platelets $\left(10^{3} / \mathrm{mcl}\right)$ & $235.30 \pm 67.85$ & $252.57 \pm 61.52$ & $281.19 \pm 76.73 \mathrm{a}$ & $\begin{array}{l}\mathrm{F}=4.177 \\
\mathrm{P}=0.018^{\star}\end{array}$ \\
\hline Serum creatinine $(\mathrm{mg} / \mathrm{dl})$ & $8.82 \pm 1.55$ & $3.31 \pm 0.67 \mathrm{a}$ & $1.78 \pm 0.30 \mathrm{a}, \mathrm{b}$ & $\begin{array}{l}\mathrm{F}=518.31 \\
\mathrm{P}<0.001^{\star}\end{array}$ \\
\hline Serum urea $(\mathrm{mg} / \mathrm{dl})$ & $129.03 \pm 37.64$ & $110.14 \pm 21.66 \mathrm{a}$ & $46.05 \pm 9.72 \mathrm{a}, \mathrm{b}$ & $\begin{array}{l}\mathrm{F}=106.02 \\
\mathrm{P}<0.001^{\star}\end{array}$ \\
\hline $\mathrm{GFR}\left(\mathrm{ml} / \mathrm{min} / 1.73 \mathrm{~m}^{2}\right)$ & $5.68 \pm 1.43$ & $19.24 \pm 4.12 \mathrm{a}$ & $41.08 \pm 9.03 \mathrm{a}, \mathrm{b}$ & $\begin{array}{l}\mathrm{F}=352.54 \\
\mathrm{P}<0.001^{\star}\end{array}$ \\
\hline
\end{tabular}

Continuous data expressed as mean \pm SD. F: one way ANOVA; P: intergroup significance; a: significance in relation to group A; b: significance in relation to group $\mathrm{B}$.

$\mathrm{ng} / \mathrm{L}$ in cases ith stage IV CKD and $165.30 \pm 50.39 \mathrm{ng} / \mathrm{L}$ in cases with stage III with high statistically signifcant difference between the three groups. This agreed with Janmaat et al. who showed that the mean serum level of iPTH was $72.8 \pm$ $49.1 \mathrm{pg} / \mathrm{ml}, 104.0 \pm 67.5 \mathrm{pg} / \mathrm{ml}, 161.1 \pm 125.5 \mathrm{pg} / \mathrm{ml}$ and $270.2 \pm 249.5 \mathrm{pg} / \mathrm{ml}$ in cases with stage $3 a, 3 b, 4$ and 5 CKD respectively, with high statistically significant difference between the four groups [7]. Also, in this study, there is a statistically significant increase in the MOF with increasing the stage of CKD $(0.46$ $\pm 0.04,0.55 \pm 0.03$ and $0.61 \pm 0.03$ in stage III, IV and V CKD respectively). This 
confirms the shortened survival of RBC with the progression of renal dysfunction. This came in agrement with Panda et al. who reported a statistically significant increase in the MOF with increasing the stage of CKD $(0.35 \% \pm 0.12 \%$, $0.48 \% \pm 0.11 \%, 0.62 \% \pm 0.07 \%$ and $0.65 \% \pm 0.66 \%$ in stage II, III A, III B and IV CKD respectively) [14]. In this study, there was a statistically significant string positive correlation between MOF and PTH levels $\left(\mathrm{r}=0.836, \mathrm{P}<0.001^{\star}\right)$ (Table 4). These data suggest that PTH is among the factors responsible for the shortened RBC survival in renal failure. In this study, the best cutoff point of PTH to detect the presence of osmotic fragility was $>265 \mathrm{ng} / \mathrm{L}$ with sensitivity of $86.6 \%$, specificity of $83.2 \%$ and total accuracy of $84 \%$ (Figure 3 ).

In the study conducted by Panda and his colleagues, ROC analysis revealed an area under the curve of 0.980 with a sensitivity of $100 \%$ and specificity of $87 \%$ in detecting osmotic fragility at a cut-off value of PTH $\geq 100 \mathrm{pg} / \mathrm{ml}$ [14]. There is also a statistically significant positive correlation between MOF with Creatinine, Urea, Phosphorous, $\mathrm{Ca}^{*}$ phosphorous product, K, KTV and PTH (Table 5).

Table 4. Analysis of the laboratory data in the three study groups (Continuation).

\begin{tabular}{|c|c|c|c|c|}
\hline Items & $\begin{array}{l}\text { Group A } \\
\text { [ESRD] } \\
(n=37)\end{array}$ & $\begin{array}{c}\text { Group B } \\
{[\text { CKD stage } 4]} \\
(n=37)\end{array}$ & $\begin{array}{c}\text { Group C } \\
\text { [CKD stage } 3] \\
(n=37)\end{array}$ & $\begin{array}{c}\text { Test of } \\
\text { significance }\end{array}$ \\
\hline Calcium (mg/dl) & $7.78 \pm 0.89$ & $8.15 \pm 0.50 \mathrm{a}$ & $8.16 \pm 0.38 a$ & $\begin{array}{c}\mathrm{F}=4.521 \\
\mathrm{P}=0.013^{\star}\end{array}$ \\
\hline Phosphorous (mg/dl) & $5.25 \pm 1.42$ & $4.83 \pm 0.93$ & $4.35 \pm 0.69 \mathrm{a}$ & $\begin{array}{c}\mathrm{F}=6.701 \\
\mathrm{P}=0.002^{\star}\end{array}$ \\
\hline $\mathrm{Ca}^{*} \mathrm{PH}$ & $40.37 \pm 10.77$ & $38.72 \pm 6.67$ & $35.47 \pm 4.89 \mathrm{a}$ & $\begin{array}{c}\mathrm{F}=3.774 \\
\mathrm{P}=0.027^{\star}\end{array}$ \\
\hline $\mathrm{Na}(\mathrm{mmol} / \mathrm{l})$ & $136.11 \pm 3.08$ & $132.05 \pm 3.16 \mathrm{a}$ & $134.51 \pm 3.72 b$ & $\begin{array}{l}\mathrm{F}=13.905 \\
\mathrm{P}<0.001^{\star}\end{array}$ \\
\hline $\mathrm{K}(\mathrm{mmol} / \mathrm{l})$ & $4.72 \pm 0.64$ & $4.57 \pm 0.54$ & $4.37 \pm 0.45 \mathrm{a}$ & $\begin{array}{c}\mathrm{F}=3.783 \\
\mathrm{P}=0.026^{*}\end{array}$ \\
\hline Iron level (mcg/dl) & $59.32 \pm 14.38$ & $62.70 \pm 13.87$ & $63.32 \pm 12.64$ & $\begin{array}{l}F=0.921 \\
P=0.401\end{array}$ \\
\hline TIBC & $201.84 \pm 48.62$ & $225.81 \pm 43.10$ & $193.32 \pm 46.18 b$ & $\begin{array}{c}\mathrm{F}=4.957 \\
\mathrm{P}=0.009^{\star}\end{array}$ \\
\hline Total saturation (\%) & $29.51 \pm 3.59$ & $28.08 \pm 4.27$ & $33.19 \pm 4.97 \mathrm{a}, \mathrm{b}$ & $\begin{array}{l}F=13.805 \\
P<0.001^{\star}\end{array}$ \\
\hline AST (U/L) & $16.08 \pm 5.31$ & $14.97 \pm 5.61$ & $17.22 \pm 5.72$ & $\begin{array}{l}F=1.512 \\
P=0.225\end{array}$ \\
\hline ALT (U/L) & $9.84 \pm 3.66$ & $10.11 \pm 4.09$ & $10.68 \pm 4.17$ & $\begin{array}{l}F=0.427 \\
P=0.654\end{array}$ \\
\hline Serum albumin (g/dl) & $3.88 \pm 0.40$ & $3.49 \pm 0.49 \mathrm{a}$ & $3.65 \pm 0.37 \mathrm{a}$ & $\begin{array}{c}\mathrm{F}=7.947 \\
\mathrm{P}=0.001^{\star}\end{array}$ \\
\hline $\mathrm{PT}(\mathrm{b} / \mathrm{min})$ & $0.15 \pm 0.02$ & $0.14 \pm 0.03$ & $0.15 \pm 0.03$ & $\begin{array}{l}F=0.242 \\
P=0.785\end{array}$ \\
\hline PTT (b/min) & $0.35 \pm 0.03$ & $0.35 \pm 0.03$ & $0.36 \pm 0.04$ & $\begin{array}{l}F=0.793 \\
P=0.455\end{array}$ \\
\hline
\end{tabular}




\section{Continued}

\begin{tabular}{ccccc}
\hline INR (b/min) & $1.22 \pm 0.20$ & $1.23 \pm 0.17$ & $1.26 \pm 0.21$ & $\mathrm{~F}=0.424$ \\
& & & & $\mathrm{P}=0.656$ \\
iPTH (ng/L) & $916.49 \pm 142.34$ & $530.27 \pm 86.25 \mathrm{a}$ & $165.30 \pm 50.39 \mathrm{a}, \mathrm{b}$ & $\mathrm{F}=517.99$ \\
& & & $\mathrm{P}<0.001^{\star}$ \\
MOF (\%) & $0.61 \pm 0.03$ & $0.55 \pm 0.03 \mathrm{a}$ & $0.46 \pm 0.04 \mathrm{a}, \mathrm{b}$ & $\mathrm{F}=192.96$ \\
& & & $\mathrm{P}<0.001^{\star}$ \\
\hline
\end{tabular}

Continuous data expressed as mean \pm SD. F: one way ANOVA; P: intergroup significance; a: significance in relation to group A; b: significance in relation to group $\mathrm{B}$.

Table 5. Correlation between MOF and other parameters in the study.

\begin{tabular}{|c|c|c|}
\hline \multicolumn{3}{|c|}{ MOF } \\
\hline variable & $\mathbf{r}$ & $\mathrm{p}$ \\
\hline Age & -0.118 & 0.218 \\
\hline HGB & -0.725 & $<0.001^{*}$ \\
\hline RBCs & -0.415 & $<0.001^{*}$ \\
\hline $\mathrm{MCV}$ & -0.063 & 0.509 \\
\hline $\mathrm{MCH}$ & -0.353 & $<0.001^{*}$ \\
\hline WBCs & 0.105 & 0.272 \\
\hline Platelets & -0.241 & $0.011^{\star}$ \\
\hline Creatinine & 0.782 & $<0.001^{*}$ \\
\hline Urea & 0.736 & $<0.001^{*}$ \\
\hline RBS & -0.057 & 0.533 \\
\hline Calcium & -0.232 & $0.014^{*}$ \\
\hline Phosphorous & 0.286 & $0.002^{*}$ \\
\hline $\mathrm{Ca}^{*}$ phosphorous product & 0.215 & $0.023^{*}$ \\
\hline $\mathrm{Na}$ & 0.131 & 0.178 \\
\hline $\mathrm{K}$ & 0.223 & $0.019^{*}$ \\
\hline Iron & -0.089 & 0.354 \\
\hline TIBC & 0.142 & 0.136 \\
\hline Saturation & -0.372 & $<0.001^{*}$ \\
\hline AST & -0.008 & 0.936 \\
\hline ALT & -0.006 & 0.953 \\
\hline Albumin & 0.082 & 0.393 \\
\hline $\mathrm{PT}$ & -0.019 & 0.846 \\
\hline PTT & -0.020 & 0.842 \\
\hline INR & -0.085 & 0.376 \\
\hline KTV & 0.734 & $<0.001^{*}$ \\
\hline PTH & 0.836 & $<0.001^{\star}$ \\
\hline GFR & -0.857 & $<0.001^{*}$ \\
\hline
\end{tabular}

R: Pearson's correlation; P: probability; ${ }^{*}$ : statistically significant $(\mathrm{P}<0.001)$. 


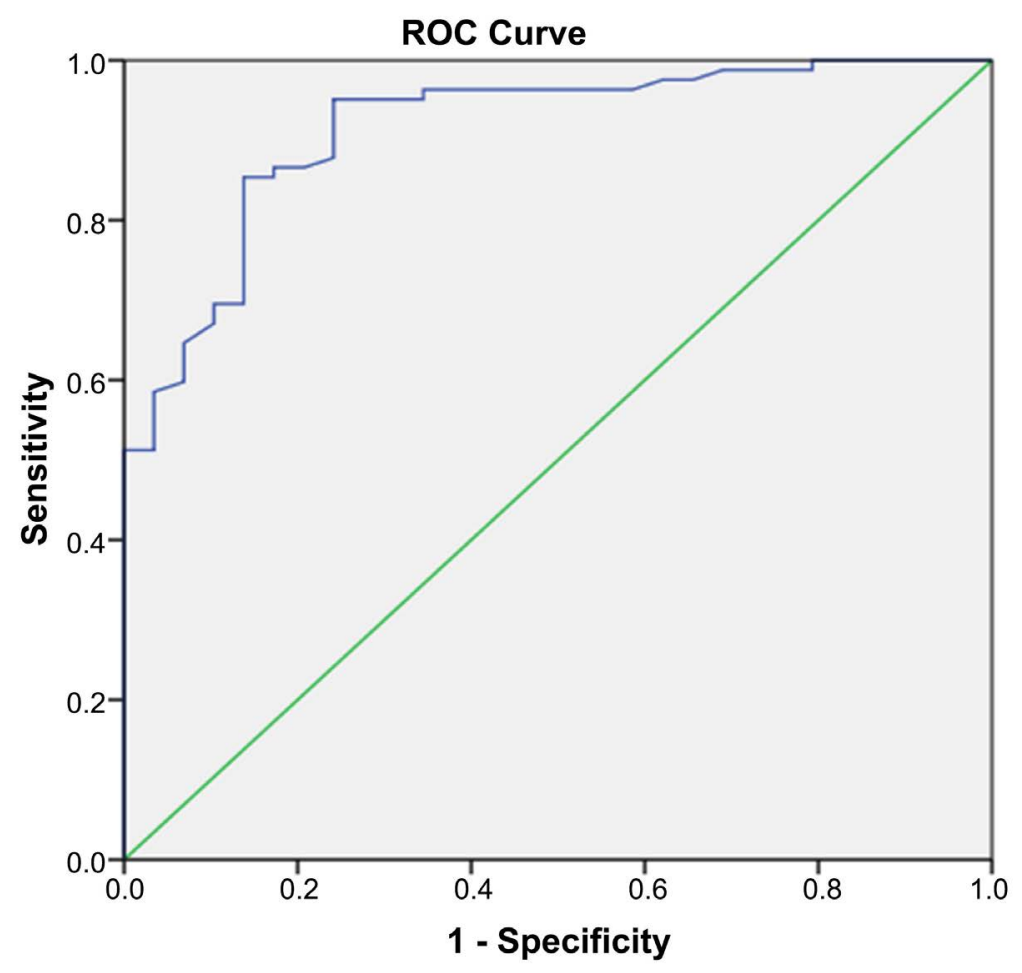

Figure 3. ROC of PTH as diagnostic of osmotic fragility.

\section{Conclusion}

Based on our findings, secondary hyperparathyroidism has considerable effects on erythrocyte survival, contributing to increased fragility and anemia. Emphasis should be laid on the early detection of serum PTH and the concomitant fall in hemoglobin levels should be treated, which in turn will help in slowing the progression of $\mathrm{CKD}$ and other associated comorbidities.

\section{Conflicts of Interest}

The authors declare no conflicts of interest regarding the publication of this paper.

\section{References}

[1] Panda, S., Mishra, A., Jena, M., Bhusanrout, S. and Mohapatra, S. (2017) Study of Red Cell Fragility in Different Stages of Chronic Kidney Disease in Relation to Parathyroid Hormone. Journal of Clinical and Diagnostic Research, 11, BC29-BC32. https://doi.org/10.7860/JCDR/2017/27344.10514

[2] Stauffer, M.E. and Fan, T. (2014) Prevalence of Anemia in Chronic Kidney Disease in the United States. Public Library of Science, 9, e84943. https://doi.org/10.1371/journal.pone.0084943

[3] Chen, L., Ling, Y.-S., Lin, C.-H., He, J.-X. and Guan, T.-J. (2015) High Dose ESAs Are Associated with High iPTH Levels in Hemodialysis Patients with End-Stage Kidney Disease: A Retrospective Analysis. Frontier in Public Health, 3, 258. https://doi.org/10.3389/fpubh.2015.00258

[4] Memon, I., Norris, K.C., Bomback, A.S., Peralta, C., Li, S.Y. Chen, S.C., et al. (2013) 
The Association between Parathyroid Hormone Levels and Hemoglobin in Diabetic and Nondiabetic Participants in the National Kidney Foundation's Kidney Early Evaluation Program. Cardiorenal Medicine, 3, 120-127. https://doi.org/10.1159/000351229

[5] Ghaderian, S.B. and Beladi Mousavi, S.S. (2014) Relationship between Parathyroid Hormone and Anemia in Uremic Patients. Journal of Parathyroid Disease, 2, 39-40.

[6] Tanaka, M., Komaba, H. and Fukagawa, M. (2018) Emerging Association between Parathyroid Hormone and Anemia in Hemodialysis Patients. Therapeutic Apheresis and Dialysis, 22, 242-245. https://doi.org/10.1111/1744-9987.12685

[7] Janmaat, C.J., Van Diepen, M., Gasparini, A., Evans, M., Qureshi, A.R., Ärnlöv, J., et al. (2018) Lower Serum Calcium Is Independently Associated with CKD Progression. Scientific Reports, 8, 1-9. https://doi.org/10.1038/s41598-018-23500-5

[8] Hemmelgarn, B., Zhang, J., Manns, B., Tonelli, M., Larsen, E., Ghali, W., et al. (2006) Progression of Kidney Dysfunction in the Community-Dwelling Elderly. Kidney International, 69, 2155-2161. https://doi.org/10.1038/sj.ki.5000270

[9] Finkelstein, F.O., Story, K., Firanek, C., Mendelssohn, D., Barre, P., Takano, T., et al. (2009) Health-Related Quality of Life and Hemoglobin Levels in Chronic Kidney Disease Patients. Clinical Journal of the American Society of Nephrology, 4, 33-38. https://doi.org/10.2215/CJN.00630208

[10] McClellan, W., Aronoff, S.L., Bolton, W.K., Hood, S., Lorber, D.L., Tang, K.L., et al. (2004) The Prevalence of Anemia in Patients with Chronic Kidney Disease. Current Medical Research and Opinion, 20, 1501-1510. https://doi.org/10.1185/030079904X2763

[11] Gowanlock, Z., Sriram, S., Martin, A., Xenocostas, A. and Lazo-Langner, A. (2016) Erythropoietin Levels in Elderly Patients with Anemia of Unknown Etiology. PLoS ONE, 11, e0157279. https://doi.org/10.1371/journal.pone.0157279

[12] Mercadal, L., Metzger, M., Casadevall, N., Haymann, J.P., Karras, A., Boffa, J.-J., et al. (2012) Timing and Determinants of Erythropoietin Deficiency in Chronic Kidney Disease. Clinical Journal of the American Society of Nephrology, 7, 35-42. https://doi.org/10.2215/CJN.04690511

[13] McMurray, J.J., Parfrey, P.S., Adamson, J.W., Aljama, P., Berns, J.S., Bohlius, J., et al. (2012) Kidney Disease: Improving Global Outcomes (KDIGO) Anemia Work Group. KDIGO Clinical Practice Guideline for Anemia in Chronic Kidney Disease. Kidney International Supplements, 2, 279-335.

[14] Panda, S., Mishra, A., Jena, M., Rout, S.B. and Mohapatra, S. (2017) Study of Red Cell Fragility in Different Stages of Chronic Kidney Disease in Relation to Parathyroid Hormone. Journal of Clinical and Diagnostic Research: JCDR, 11, BC29. https://doi.org/10.7860/JCDR/2017/27344.10514 